\title{
Inovasi Pembelajaran Kewirausahaan Islami melalui Pemanfaatan Teh Rosella pada Kantin Sehat SMP
}

\section{Islamic Entrepreneurship Learning through the Utilization Rosella Tea in Healthy Canteen School}

\author{
Eni Fariyatul Fahyuni ${ }^{1}$, Jamilatur Rohmah ${ }^{2}$, Najih Anwar ${ }^{3}$ \\ ${ }^{1,2,3}$ Universitas Muhammadiyah Sidoarjo \\ eni.fariyatul@umsida.ac.id, ${ }^{2}$ jamilaturrohmah@umsida.ac.id, ${ }^{3}$ najihanwar@umsida.ac.id
}

Riwayat Artikel: Dikirim 14 Januari 2019; Diterima 10 Mei 2019; Diterbitkan 31 Mei 2019

\begin{abstract}
Abstrak
Pembelajaran kewirausahaan Islami sangat diperlukan guna dapat membangun dan membentuk kecakapan siswa berwirausaha. Potensi SMPN 2 Porong memiliki area pekarangan yang banyak tumbuh bunga Rosella. Permasalahan yang kemudian muncul adalah bagaimana cara membelajarkan kewirausahaan siswa kaitannya dengan potensi bunga Rosella yang melimpah di sekolah. Metode pelaksanaan pengabdian masyarakat ini mengunakan pendekatan edukatif, meliputi: 1) melakukan sosialisasi dan pengurusan perijinan, 2) persiapan penyuluhan, 3) kegiatan penyuluhan, 4) kegiatan praktik dan pendampingan, 5) melakukan kegiatan evaluasi dan monitoring untuk mengetahui ketercapaian dari program yang telah dilaksanakan. Pembelajaran kewirausahaan melalui pemanfaatan teh bunga Rosella dapat meningkatkan kreativitas siswa menuju suatu pembaharuan.
\end{abstract}

Kata kunci: pembelajaran kewirausahaan islami, pemanfaatan teh bunga rosella.

\begin{abstract}
Islamic entrepreneurship is needed to be able to build entrepreneur skills. The potential Porong 2 at state midlle School has grows a lot of Rosella flowers. The problem is how to teach entrepreneurship with Rosella flowers at school. The method uses an educational approach, including: 1) conducting socialization and permits of management, 2) preparation of counseling, 3) counseling activity, 4) practice and mentoring activities, 5) evaluation and monitoring activities to find out an achievements programs. Entrepreneurship through the use of Rosella flower tea can increase students' creativity towards renewal.
\end{abstract}

Keywords: Islamic entrepreneurship learning, utilization of rosella tea.

\section{PENDAHULUAN}

\section{Latar Belakang Masalah}

Pendidikan SMP menerapkan kegiatan belajar dan mengajar bertujuan membentuk watak dan kepribadian siswa mengembangkan potensi dirinya secara berkelanjutan. Hal in sesuai yang diungkapkan Djatmiko (1988) “.....bahwa perlakuan untuk mendidik wirausaha pada masa remaja adalah melalui pelatihan untuk siswa memahami lingkungan kerja sesungguhnya". Pembelajaran kewirausahaan sangat diperlukan guna dapat membangun dan membentuk kecakapan siswa berwirausaha.
Kewirausahaan adalah suatu kemampuan seseorang untuk membangun ide, pemikiran, dan tindakannya secara kreatif dan inovatif serta memiliki keberanian dan perhitungan yang matang dalam menghadapi berbagai resiko yang ada. Dalam Al Quran Surat Al Jumu'ah ayat 10, Allah berfirman: "apabila telab ditunaikan shalat, Maka bertebaranlab kamu di muka bumi; dan carilah karunia Allah dan ingatlah Allah sebanyak-banyaknya supaya kamu beruntung".

$$
\text { Siagian dan Asfahani }
$$
mengatakan pendidikan kewirausahaan dapat mempengaruhi dan meningkatkan kesuksesan berwirausaha seseorang di masa depan. Tiga modal utama menjadi 
wirausahawan, diantaranya: 1) membuat kesempatan baru (opportunity creating), 2) melakukan inovasi usaha baru (innovation), 3) berani mengambil tantangan (calculated risk taking). Memasuki abad 21, pembelajaran seharusnya berubah dari teacher center menuju student center (Fahyuni \& Istikomah, 2016). Halini dipertegas dalam Al Quran Surat Al Mulk ayat 15, Allah berfirman "Dialah yang menjadikan bumi itu mudah bagi kamu, Maka berjalanlah di segala penjurunya dan makanlah sebahagian dari rękiNya dan hanya kepada-Nya-lab kamu (kembali) dibangkitkan".

Dengan demikian sesuai Keputusan Menteri Pendidikan dan Kebudayaan Nomor 0461/ U/ 1984, tentang Pola Pembinaan dan Pengembangan Kesiswaan adalah dilaksanakan program pembinaan ketrampilan dan kewirausahaan siswa di sekolah melalui berbagai bidang diantaranya koperasi dan kantin sekolah. Pembelajaran kewirausahaan perlu guna dapat merespon berbagai kesempatan menuju kesuksesan berwirausaha (Suryana, 2006).

Gambar 1.

Tempat kantin sehat SMPN 2 Porong

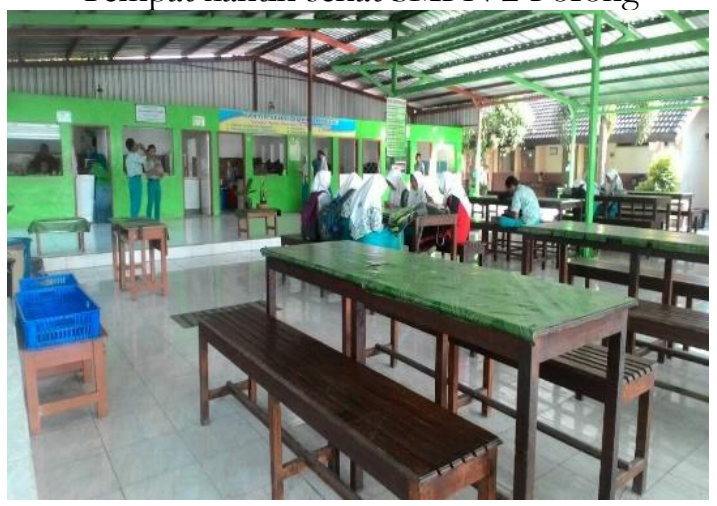

Permasalahan yang kemudian muncul adalah, bagaimana cara membelajarkan kewirausahaan pada siswa di sekolah. Permasalahan inilah yang menjadi bidang kajian dalam pengabdian masyarakat di SMPN 2 Porong.

SMPN 2 Porong terletak di jalan Candiwangkal desa Lajuk kecamatan porong. Sekolah ini pada tahun 2018 merupakan salah satu sekolah percontohan pada kantin sehatnya, di mana berbagai jenis makanan dan minuman yang dijual tidak diperbolehkan menggunakan bungkus atau alas berbahan plastik. Begitupula pada minuman yang dijual pada kantin tersebut sama sekali tidak mengunakan gelas atau wadah berbahan dasar plastik dari gelas kaca. Beragam jenis makanan dan minuman yang dijual pada kantin sehat SMP seperti nasi pecel, nasi soto, bakso, dan nasi goreng. Sedangkan jenis minuman yang tersedia diantaranya aneka jus buah seperti mangga, alpukat, jambu serta terdapat minuman teh hangat maupun dingin. Sanitasi kantin ditetapkan untuk meningkatkan layanan kantin bagi seluruh warga sekolah sebagai konsumen.

Gambar 2.

Siswa Berjualan di Kantin

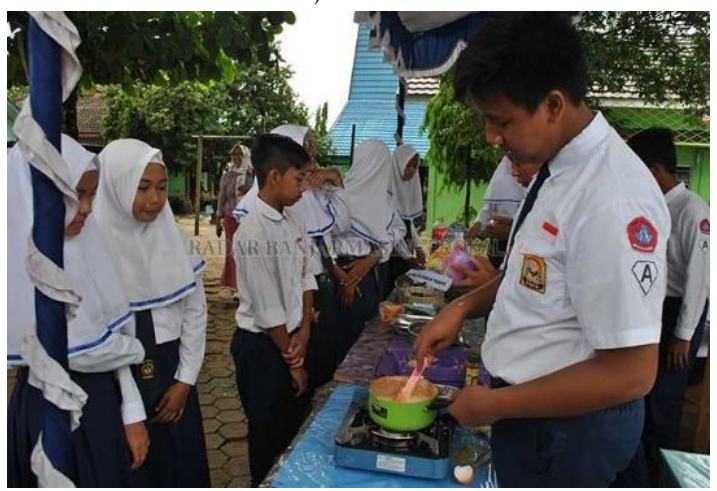

Potensi SMPN 2 Porong tidak hanya memiliki fasilitas berupa kantin sehat, namun juga pada area pekarangan sekolah banyak tumbuh bunga Rosella dengan bentuk buah menyerupai kelopak bunga berwarna merah menyala. Banyak kegunaan dan manfaat Rosella diantaranya dapat meningkatkan kemampuan fisik dan daya tahan tubuh karena kandungan vitamin $\mathrm{C}$ yang sangat tinggi (Ekanto \& Sugiarto, 2011). 
Gambar 3.

Bunga Rosella di SMPN 2 Porong

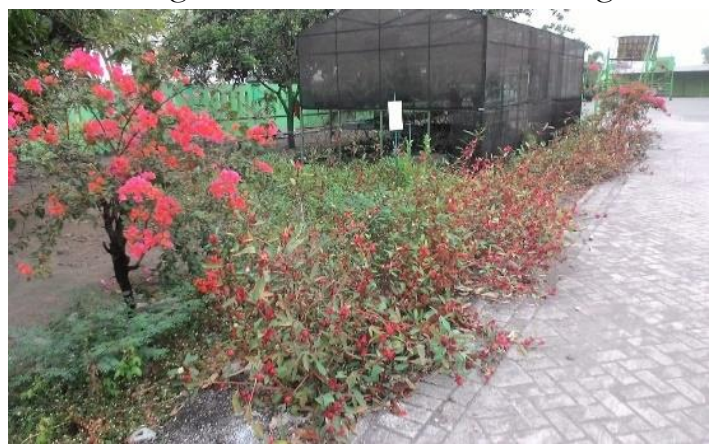

Dengan begitu banyaknya khasiat dan manfaat yang dihasilkan dari tanaman Rosella ini menjadikan warga sekolah SMPN 2 Porong didukung tim pengabdian masyarakat dari Fakultas Agama Islam bekerjasama dengan Fakultas Ilmu Kesehatan dari Universitas Muhammadiyah Sidoarjo berinovasi mengembangkan pembelajaran kewirausahaan dengan memberikan pelatihan pemanfaatan teh bunga Rosella menjadi minuman teh yang aman dikonsumsi dan menyehatkan.

\section{Rumusan Masalah}

Permasalahan yang ada adalah bagaimana upaya guru dalam membelajarkan kewirausahaan Islami pada siswa SMP melalui pemanfaatan teh bunga Rosella?

Islam mengajarkan manusia untuk menguasai keahlian atau keterampilan tertentu dalam rangka melaksankan tugasnya sebagai khalifah di muka bumi. Al Quran surah Al Qashash ayat 77 telah menganjurkan manusia untuk mempelajari berbagai ilmu pengetahuan dan bidang keterampilan tertentu. Menurut Soemanto (1996), untuk menjadi seorang wirausahawan yang baik dibutuhkan antara lain:

1. Berfikir kreatif dan innovatif

Seorang wirausahawan harus memiliki jiwa sportif dan tanggungjawab yang didukung dengan kemampuan berfikir kreatif dan inovatif seseorang terhadap berbagai peluang yang ada. Allah berfirman dalam AL Quran "....Kemudian Kami jadikan dia (manusia) makbluk yang unik. Maka Maha Sucilah Allah, Pencipta Yang Paling Baik." (QS. Al Mu'min [23]: 12-14). Adapun yang enyebabkan kreativitas seseorang tidak berkembang secara optimal adalah karena seseorang tidak peka dalam merespon dan memecahkan berbagai persoalan yang ada sehingga mampu menjadikannya sebagai khalifah di muka bumi.

\section{Keterampilan problem solving}

Pengambilan keputusan merupakan suatu keterampilan yang wajib dan perlu dimiliki oleh seseorang sebagai alternatif pemilihan atas berbagai masalah yang dihadapinya. Orang yang kreatif mampu menghasilkan problem solving yang tidak akan merugikan berbagai pihak yang terlibat. Seorang pemimpin yang baik akan selalu memberikan semangat dan keleluasaan bagi orang lain maupun dirinya sendiri untuk problem solving yang dapat dipertanggungjawabkan.

3. Keterampilan menjadi pemimpin

Seorang pemimpin yang baik akan berpengaruh pada anak buah ataupun anggota yang dipimpinnya. Oleh karenanya diperlukan kualitas sikap dan attitude seseorang guna tercapainya tujuan bersama. 4. Keterampilan bergaul

Seorang wirausaha mampu membangun komunikasi yang baik dengan yang lainnya, mengenal berbagai karakter orang yang ditemuinya. Adapun cara bergaul yang baik dan efektif adalah mampu menghormati dan menghargai ide dan pemikiran orang lain, memberikan pelayanan terbaik serta menjaga penampilan dan ucapannya. 


\section{METODE}

\section{Metode Pelaksanaan}

Pelaksanaan pengabdian masyarakat melalui pendekatan edukatif dengan memberikan pelatihan guna meningkatkan keterampilan hidup (life skill) siswa SMPN 2 Porong melalui pelatihan pemanfaatan teh bunga Rosella.

\section{Gambar 3}

Tahapan pemanfaatan teh bunga Rosella

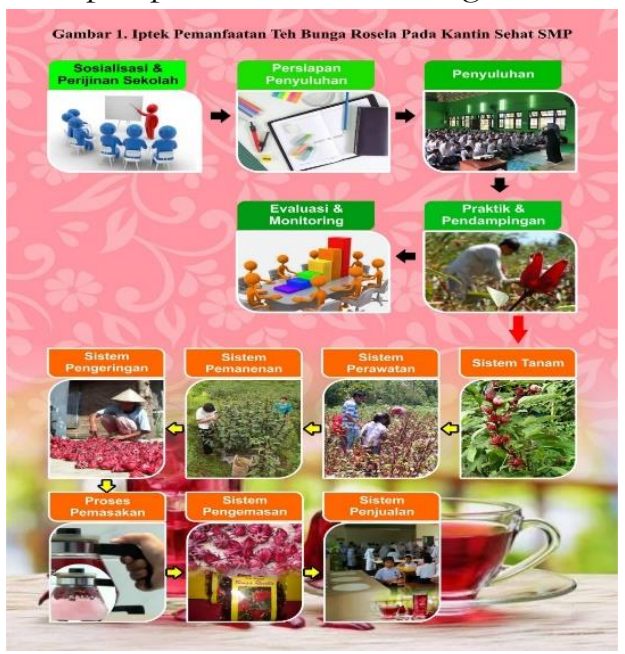

Adapun tahapan pemanfaatan teh bunga Rosella adalah sebagai berikut: 1) melakukan sosialisasi tanaman Rosella dan pengurusan surat perijinan ke sekolah, 2) persiapan penyuluhan kaitannya dengan kelengkapan perangkat dan alat yang digunakan, 3) kegiatan penyuluhan yang melibatkan dinas kesehatan dan pembelajaran kewirausahaan yang melibatkan dosen bidang ilmu ekonomi syariah, 4) kegiatan praktik dan pendampingan langsung meliputi sistem tanam bunga Rosella, sistem perawatannya, sistem pemanenan, sistem pengeringan, proses pemasakan, sistem pengemasan, hingga sistem penjualan yang dapat dipelajari oleh siswa setingkat SMP, dan yang terakhir, 5) melakukan kegiatan evaluasi dan monitoring untuk mengetahui ketercapaian dari program yang telah dilaksanakan.

\section{PROSEDUR}

\section{Sistem Penanaman}

Sistem penanaman bunga Rosella sangat dipengaruhi oleh faktor lingkungan meliputi intensitas cahaya matahari, penyiraman air, temperature/suhu, dan unsur hara (Retnaningrum, 2001).

Gambar 4.

Kelopak bunga Rosella

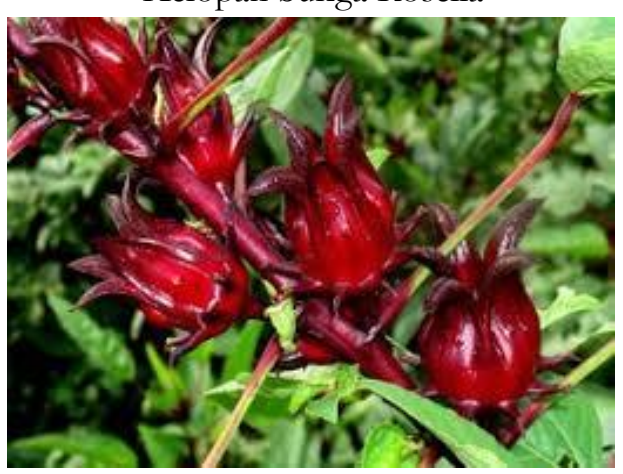

Manfaat bunga Rosella salah satunya dapat menurunkan tekanan darah tinggi (Rohaendi, 2008; Munim et al, 2008) dapat menghambat radikal bebas. Adapun cara membudidaya tanaman Rosella ini tidak membutuhkan biaya perawatan yang tinggi karena hanya dibiarkan tumbuh dan sesekali diperhatikan kebutuhan airnya. Berikut ini kegiatan praktik dan pendampingan terkait sistem tanam Rosella agar dihasilkan kelopak bunga maksimal antara lain (Munim, 2008).

\section{Persiapan lahan}

Sosialisasi ke siswa sebelum dilakukan penanaman, tanah harus digemburkan terlebih dahulu agar terkena sinar matahari yang merata dengan sistem pengairan yang tercukupi. Tanah memiliki unsur yang sangat penting bagi pertumbuhan tanaman Rosella. Untuk itu persiapan lahan tanam sangat penting diperhatikan guna menunjang kualitas dan peningkatan hasil panen bunga Rosella. Lahan tanam harus sering dikontrol agar airnya tidak kering maupun tidak terlalu basah. 


\section{Jarak tanam}

Ukuran jarak tanam Rosella bergantung dari jenis, waktu tanam, dan tingkat kesuburan tanah. Pembibitan tanaman Rosella harus terpisah dari tanaman dewasa lainnya, ini disebabkan hama dan penyakit pada tanaman mudah berpindah tempat. Cara tanamnya bunga Rosella adalah bibit dimasukkan lubang tanah dengan kedalaman 3-4 cm.

Untuk menghasilkan bibit Rosella yang baik adalah dengan dilakukan perendaman bibit sebelumnya selama hampir 12 - 24 jam sebelum dilakukan penanaman. Benih yang digunakan adalah berasal dari pemanenan pertama saat biji telah mencapai pertumbuhan yang lengkap dan ukurannya yang paling besar agar dapat menghasilkan bakal tanaman baru yang lebih kuat dan besar. Ditinjau dari sudut fisiologi tanaman Rosella ini banyak dipengaruhi oleh cahaya matahari. Jarak tanam sangat bergantung kondisi tanah. Tanah yang subur akan memberikan pertumbuhan yang baik pula. Jarak tanam Rosella idealnya berukuran $12 \times 12 \mathrm{~cm}, 15 \times 15$ $\mathrm{cm}, 12,5 \times 15 \mathrm{~cm}, 12,5 \times 20 \mathrm{~cm}$, dan atau $20 \times 20 \mathrm{~cm}$.

Gambar 5.

Jarak tanam Rosella

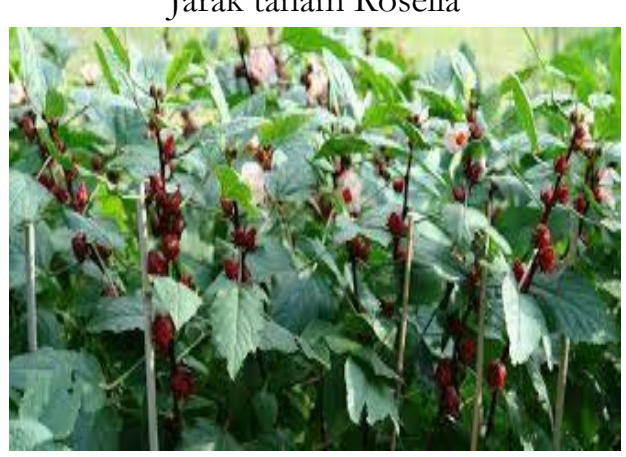

\section{Waktu tanam}

Tanaman Rosella merupakan jenis tanaman berbunga bergantung pada musim dengan masa tanam sekitar 2,5 hingga 3 bulan saja.

Pembungaan Rosella yang maksimal terjadi pada siang hari dan waktu terbaik untuk penanaman Rosella di pulau jawa ini yaitu pada musim kemarau pada pertengahan bulan Agustus dan akhir Desember.

\section{Pemeliharaan Bunga Rosella}

Pada umumnya bibit tanaman Rosella mulai tumbuh setelah $2-3$ hari masa bertanam. Lubang tanaman yang tidak tumbuh dapat ditanami kembali pada hari ketiga setelah tanaman Rosella lainnya sudah tumbuh semua. Hal ini dilakukan dengan tujuan waktu pemanenan antara tanaman Rosella yang satu dengan yang lainnya tidak berbeda jauh waktunya. Tanaman Rosella pada usia 2 minggu harus dilakukan penyiangan untuk membersihkan dan mencabut tanaman liar disekitar tanaman Rosella.

Gambar 6.

Waktu tanam Rosella

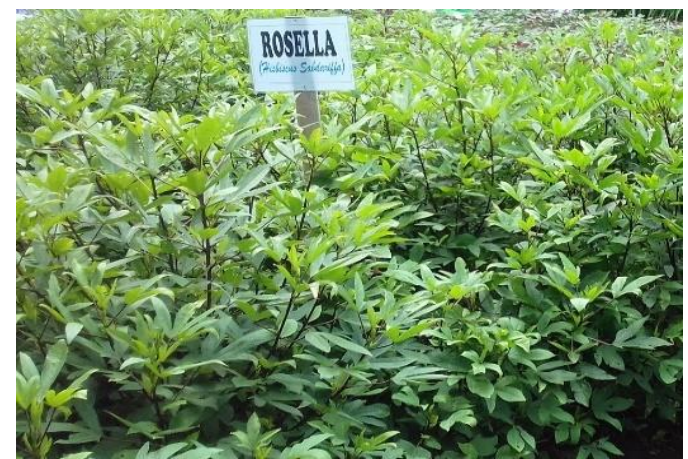

Penyiangan tanaman liar harus dilakukan secara rutin minimal 1 minggu sekali apalagi pada musim penghujan dimana rumput cepat sekali tumbuh dengan suburnya.

Gambar 7.

Tanaman liar

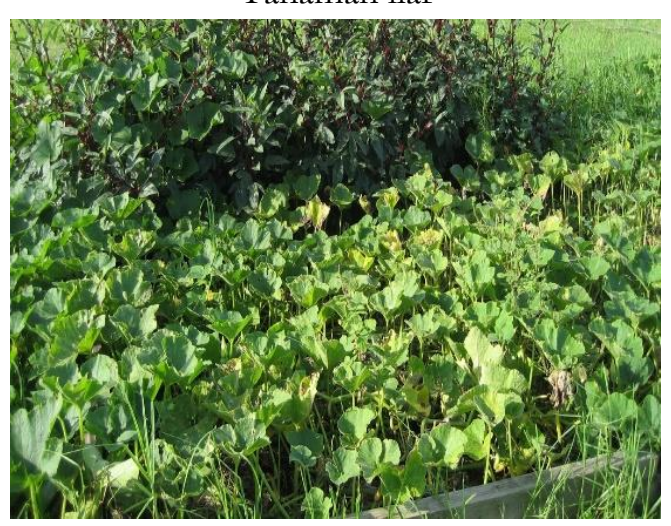


Penyiangan ini rutin dilakukan agar tanaman Rosella tumbuh subur sehingga bunga yang dihasilkan juga berkualitas. Jika pada musim kemarau, tanaman Rosella ini banyak membutuhkan air untuk pertumbuhannya. Sistem pengairan pada umumnya melalui selokan, parit, dan bedengan dengan kapasitas debit air yang rendah.

\section{Proses Pemanenan}

Tanaman Rosella ini dapat dipanen sejak awal tanam kurang lebih hanya membutuhkan waktu 3 bulan saja, untuk selanjutnya tanaman ini masih terus dapat menghasilkan bunga hingga tanaman mengering dan mati dengan sendirinya. Proses pemanenan dapat dilakukan secara manual maupun dengan alat. Hal yang perlu diperhatikan saat pemanenan adalah hasil panen atau bunga Rosella tidak terkontaminasi dengan benda-benda lainnya yang kurang bersih dan banyak mengandung virus penyakit.

\section{Proses Pengeringan}

Kelopak bunga Rosella yang telah dipanen biasanya mengandung kadar air yan tinggi (sekitar 85\%). Oleh karenanya diperlukan serangkaian proses pengeringan untuk mengurangi kadar airnya yang tinggi hingga mencapai 14\% (sesuai keinginan pasar (Suherman, 2012).

Tekstur dan warna merah menyala pada bunga Rosella setelah dikeringkan pada umumnya tidak mengalami perubahan yang mencolok setelah kering, yakni berubah warna menjadi merah tua. Perubahan ini terjadi karena kadar airnya bunga Rosella menyusut selama dilakukan proses pengeringan.
Gambar 8.

Bunga Rosella kering

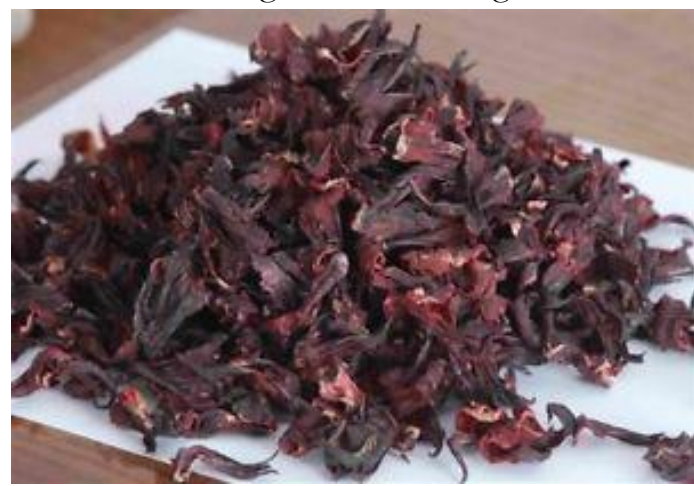

Proses Pemasakan

Proses pemasakan hingga menjadi jenis minuman teh dari bunga Rosella dapat dilakukan melalui dua cara, yakni dengan cara menyeduh/merebus bunga Rosella kering maupun Rosella basah yang belum diawetkan/dikeringkan.

Cara membuatnya: 1) rebus $600 \mathrm{ml}$ air dengan api kecil hingga mendidih, 2) masukan bunga Rosella basah/kering ke dalam air beserta kayumanis, cengkih untuk menambah aroma, 3) setelah mendidih, masukkan gula batu/gula aren, aduk hingga rata dan air berubah kemerahan selanjutnya minumlah selagi hangat.

Gambar 9.

Teh bunga Rosella

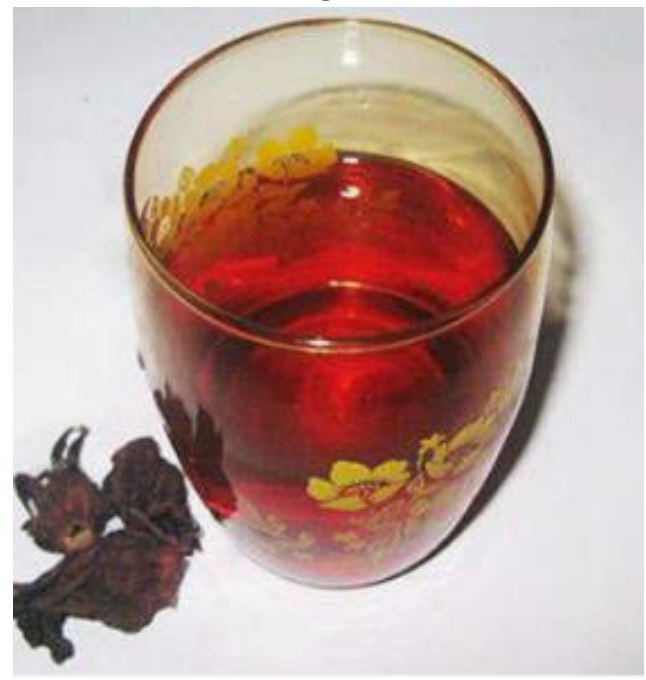




\section{Proses Pengemasan}

Proses pengemasan teh bunga Rosella merupakan salah satu cara terpenting terhadap produk, makanan, dan atau bahan pangan yang dihasilkan untuk bisa sampai pada konsumen tentunya dengan memperhatikan segi kuantitas dan kualitas produk di dalamnya.

Kemasan memiliki makna sesuatu yang digunakan untuk mengemas dan atau membungkus barang untuk menarik minat pembeli sekaligus memberikan perlindungan keamanan dan mencegah kerusakan dari lingkungan sekitar.

Proses pengemasan teh bunga Rosella sangat simpel dan sederhana sehingga semua peserta didik di SMPN 2 Porong dapat terlibat aktif dalam mengemas dan mendesain kemasan teh bunga Rosella sesuai ide kreativitas mereka. Kemasan bisa dalam bnetuk ukuran 100 gram yang dibungkus plastik dengan telah dibuat gambar dan keterangan teh bunga Rosella. Kemasan lainnya bisa juga dalam bentuk minuman di botol (instan) siap saji untuk bisa langsung dinikmati pembeli.

\section{Sistem Pemasaran}

Sistem pemasaran pada produk teh bunga Rosella dalam bentuk kering siap seduh yang dikemas pada bungkus plastik 100 gram dengan kisaran harga Rp. 15.000. Segmen pemasaran selama ini masih seputar lingkungan sekolah utamanya memenuhi kebutuhan kantin sehat sekolah yang setiap harinya membutuhkan 4 bungkus atau 400 gram teh bunga Rosella kering dengan jumlah konsumen kantin yang terdiri dari 884 siswa dan 57 tenaga pendidik.

Untuk pemasaran lainnya biasanya guru atau bahkan siswa yang biasanya diminta oleh orangtuanya untuk membelikan teh bunga Rosella kering yang dapat digunakan sebagai minuman teh saat mereka dirumah. Omzet yang didapat dari hasil penjualan teh bunga Rosella adalah mencapai Rp. 3.000.000 setiap bulannya. Uang hasil penjualan teh bunga Rosella ini nantinya tidak diberikan dalam bentuk uang kepada setiap siswa yang terlibat, namun uang hasil jerih payah mereka akan ditabung di guru gelas atau koordinator kesiswaan untuk selanjutnya uang tersebut digunakan untuk membiayai perjalanan study banding siswa, biaya mengikuti LDKS (pelatihan leadership) yang diprogramkan sekolah.

Gambar 10.

Kemasan teh bunga Rosella

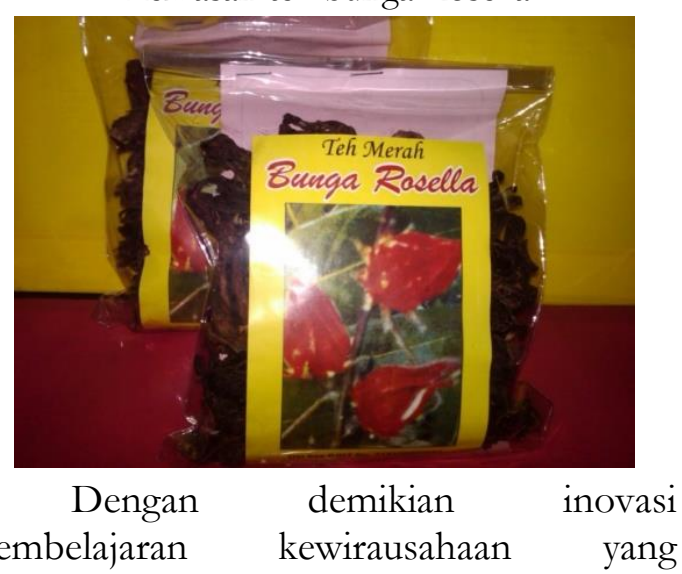

diterapkan di sekolah melalui pemanfaatan teh bunga Rosella dapat langsung dialami, dirasakan, dan dinikmati oleh siswa baik secara individu maupun bersama-sama dalam komunitas belajar mereka dengan memaksimalkan potensi siswa maupun lingkungan SMPN 2 Porong.

\section{HASIL DAN PEMBAHASAN}

Program Pengabdian Bagi Masyarakat (IbM) ini merupakan salah satu kegiatan rutin yang didanai oleh institusi UMSIDA dalam rangka mengembangkan kemajuan ilmu pengetahuan dan teknologi guna meningkatkan kesejahteraan dan kesehatan pangan bagi masyarakat sekolah. Kegiatan IbM ini menitikberatkan pada siswa kelas VII, VIII, dan IX sebagai upaya membelajarkan kewirausahaan dimulai dari lingkungan belajar mereka.

IbM ini meliputi beberapa kegiatan diantaranya:

1. Tahap perijinan dan sosialisasi pada SMPN 2 Porong pada tanggal 10 Desember 2018. Selanjutnya pemetaan permasalahan beserta solusi yang akan ditawarkan. 
2. Tahap penyuluhan kaitannya dengan kelengkapan perangkat dan alat yang digunakan selama kegiatan berlangsung yang melibatkan dinas kesehatan dan pembelajaran kewirausahaan yang melibatkan dosen bidang ilmu ekonomi syariah.

3. Tahap kegiatan praktik dan pendampingan langsung meliputi sistem tanam bunga Rosella, sistem perawatannya, sistem pemanenan, sistem pengeringan, proses pemasakan, sistem pengemasan, hingga sistem penjualan yang dapat dipelajari oleh siswa setingkat SMP.

4. Tahap melakukan kegiatan evaluasi dan monitoring untuk mengetahui ketercapaian dari program yang telah dilaksanakan. Berdasarkan hasil kegiatan evaluasi dan monitoring inilah dapat di cek berbagai kekurangan dan faktor penghambat yang ada di lapangan.

Pembelajaran kewirausahaan berhubungan dengan kemampuan seseorang dalam memanfaatkan berbagai peluang dan berani mengambil resiko serta mampu menciptakan peluang baru. Siagian (1999) bahwa kewirausahaan adalah sikap, semangat, dan etos diri seseorang dalam merespon positif berbagai peluang. Meredith et. al (1992) mengatakan kemampuan seseorang dalam melihat, mengumpulkan berbagai informasi dan mampu menganalisis serta mengambil sebuah tindakan secara cepat dan tepat dari hasil kreativitas dan inovasi yang dikembangkannya.

\section{KESIMPULAN}

Di era kemajuan teknologi dan informasi saat ini, terdapat banyak peluang dalam mengembangkan pembelajaran kewirausahaan di sekolah, salah satunya melalui pemanfaatan teh bunga Rosella. Proses berwirausaha diawali adanya inovasi untuk menjawab kebutuhan dan peluang bisnis yang dijalankan. Pembelajaran kewirausahaan melalui pemanfaatan teh bunga Rosella dapat meningkatkan kreativitas siswa menuju suatu pembaharuan.

Inovasi yang dikembangkan dalam pembelajaran kewirausahaan melalui pemanfaatan teh bunga Rosella akan berdampak positif pada sifat, karakter, dan perilaku sehari-hari siswa.

Terdapat beberapa faktor yang dapat mempengaruhi kewirausahaan siswa SMPN 2 Porong yakni: 1) kepercayaan diri, 2) komitmen, inisiatif dan optimis menghadapi berbagai tantangan dan perubahan yang terjadi. Pentingnya jiwa kewirausahaan akan dapat membimbing dan mengarahkan pada suatu peluang usaha yang akan dijalani.

\section{DAFTAR PUSTAKA}

Ekanto, B. (2011). Kajian Teh Rosella (Hibiscus sabdariffa) dalam Meningkatkan Kemampuan Fisik Berenang (Penelitian Eksperimen Pada Mencit Jantan Remaja). Media Ilmu Keolahragaan Indonesia, 1(2).

Fahyuni, E. F., \& Istikomah, I. (2016). Psikologi Belajar \& Mengajar (kunci sukses guru dalam interaksi edukatif). Sidoarjo: Nizamia Learning Center. 2016, cet ke-1

Meredith, Geofrey g., et. al.. (1992). Kewirausahaan : Teori dan Praktek, Jakarta: PT Binaman Pressindo.

Munim, A., Hanani, E., \& Mandasari, A. (2008). Pembuatan teh herbal campuran kelopak bunga rosella (Hibiscus sabdariffa) dan herba seledri (Apium graveolens). Pharmacentical Sciences and Research (PSR), 5(1), 47-54.

Raharjo, T. J., Suminar, T., \& Muarifuddin, M. (2016). Peran pusat kegiatan belajar masyarakat dalam menanggulangi kemiskinan melalui pendidikan nonformal di Jawa Tengah. Journal of Nonformal Education, 2(1), 21-38.

Retnaningrum. (2001). Pembungaan dan Faktor-faktor yang Mempengarubi. http://jakarta.litbang.deptan.go.id/ klinikagribisnis/index.p?option $=\mathrm{cO}$ 
ntent\&task $=$

view\&id $=27 \&$ Itemid $=67$.

Desember 2007.

Rohaendi, H. (2008). Pengaruh Pemberian

Teh Rosella Terhadap Tekanan

Darah Pasien Hipertensi Primer di

Panti Jompo Welas Asih Kota

Tasikmalaya. Fakultas Ilmu

Keperawatan, Universitas Indonesia, 66-

84.

Siagian dan Asfahani. (1995). Kewirausahaan

Indonesia dengan semangat 17.8.45.

Jakarta: Kloang Klede Jaya PT Putra

Timur bekerjasama dengan

Puslatkopdan PK Depkop dan PPK.

Suryana, D., \& Si, M. (2006). Kewirausahaan: Pedoman Praktis (Kiat dan proses menuju sukses). Jakarta: Salemba Empat.

Yuariski, O., \& Suherman, S. (2012). Pengeringan Bunga Rosella (Hibiscus Sabdariffa) Menggunakan Pengering Rak Udara Resirkulasi. Jurnal Teknologi Kimia dan Industri, 1(1), 1-6. 